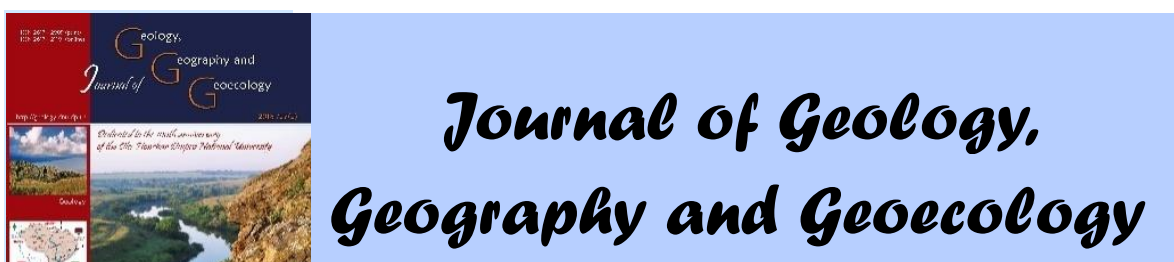

Journal home page: geology-dnu-dp.ua

\title{
Lithofacial and paleogeographic analysis of the Burdigallian-Langhian formations of the Ukrainian Carpathian Foredeep
}

\author{
O.M. Cheremisska, Yu.V. Cheremissky
}

Institute of Geology and Geochemistry of Combustible Minerals of NASU, Lviv, Ukraine, o.cheremisska@gmail.com

Received 09.12.2018;

Received in revised form 16.12.2018;

Accepted 15.03.2019
Abstract. This paper addresses issues related to the complexity of the geological structure of the Burdigallian-Langhian sediments of the Stebnyk suite, which were formed in the Carpathian segment of Paratethys. The correlation of stratigraphic sections, based on a detailed description of the most complete sediments of the indigenous outcrops of the Stebnyk suite in the Sambir Unit of the Pre-Carpathian Foredeep, has been carried out. It was established that the sediments belong to a single tectono-sedimentation cyclic, the formation of which began with the deposition of red-coloured sediments and ended with the deposition of salt-bearing formations, which indicates the final closure of the Paratethys. A series of lithological columns was constructed taking into account the disjunctive and plicating faults, which allowed us to derive the true thickness of the Stebnyk suite deposits and determine its lithofacial structure. The results obtained became the basis for the construction of a lithological scheme for the distribution of lithofacies and a paleooceanographic sedimentation model of the research area. The aim of this work is to create a reconstruction of the environment of sedimentation in the Burdigallian-Langhian Age in the Sambir Unit of the Inner part of the Pre-Carpathian Foredeep. To obtain the results, the actual material obtained during the field observations was analyzed with the help of a complex of lithology-facial, geodynamical and petrographic methods. Due to the absence of the reliable paleontological data on deposits of the Miocene Stebnyk suite of the PreCarpathian basin, an attempt was made to partition the Stebnyk sedimentary sequence on lithological and formation features, based on the author's research and with incorporation of new materials of paleooceanography of the Carpathian segment of the Paratethys. On the basis of paleooceanographic data, connected with formation of sedimentary strata of Stebnyk suite (Carpathian basin), the latter can be attributed to the red-coloured formation of foothill plains and deltas. Taking into account the data of the researchers and their own observations, one can come to the conclusion that the age of the sediments, mapped on existing geological maps as Vorotyshcha suite in considerable areas of Sambir Unit (near the villages of Krasne, Pidlyvche, Lysovychi) is questionable. This conception required the stratification of deposits formed on the stage of sedimentogenesis in the Miocene within the studied segment of the Central Paratethys. For the first time for depositions of this age, the scheme of the palaeoceanographic situation and a lithological-facial model of the sedimentation environment with the reduction of the true thickness of sediments was constructed. The Burdigallian-Langhian deposits were formed under conditions of lacustrine-alluvial plains of arid climate, symbolizing the final closure of the Central Paratethys. The presence of a detailed model for the formation of Burdigallian-Langhian deposits allows us to identify a number of criteria for the search for minerals.

Keywords: lithology; miocene; pre-carpathian foredeep; stebnyk suite; geogeneration; paratethys.

\section{Літолого-фаціальний та палеогеографічний аналіз бурдигал-ллангійських відкладів прогину Українських Карпат}

\section{О. М. Черемісська, Ю. В.Черемісський}

\section{Інститут геології і геохімії горючих копалин НАН Украӥни, Львів, Украӥна, о.cheremissska@gтаil.com}


що вік відкладів воротищенської світи, нанесеної на існуючі геологічні карти на значних ділянках Самбірської зони (поблизу селищ Красне, Підльве, Лисовичі) викликає сумнів. Дана концепція вимагала стратифікації відкладень, що утворюються на стадії седиментогенезу в міоцені в досліджуваному сегменті Центрального Паратетісу. Вперше для відкладів цього віку побудована схема палеоокеанографічної ситуації та літолого-фаціальна модель обстановки осадконагромадження 3 приведенням істинної потужності відкладів. Встановлено, що бурдигал-лангійські відклади формувалися в умовах озерно-алювіальних рівнин в аридному кліматі, що символізує остаточне закриття Центрального Паратетісу. Наявність детальної моделі формування бурдигал-ллангійських відкладів дозволяє виділити ряд критеріїв, необхідних для пошуків корисних копалин.

Ключові слова: літологія, міочен, передкарпатський прогин, стебницька світа, геогенераиія, паратетіс.

Introduction. On the basis of paleooceanographic data, connected with the formation of sedimentary strata of the Stebnyk suite (Carpathian basin), the latter can be attributed to the variegated formation of foothill plains and deltas (Van Houten, 1964). The studied deposits are widespread in the Sambir Unit of the Inner Unit of the Carpathian Foredeep (Kulchytsky, 1977). On the basis of detailed research on the Carpathians, R. Zuber (Zuber, 1883) concluded conjugation of potash salts with variegated "shales". A century later, V. Hlushko and Ya. Kulchytsky (Glushko, Kulchytsky, 1995) noted that the Badenian age of the Kalush salt layers was proven, but that the stratigraphic position of the salt deposits was uncertain (areas of villages Lanchyn and Rungury), where they are deposited directly on Stebnyk beds. These researchers have actualized the issue of the stratigraphic position of the Balych beds. So, L. Pishvanova (Burov and others, 1971) draw attention to the similarity of the Balych and Stebnyk deposits, as evidenced by the presence in them of cupreous sandstone mineralization with a minor feature of the red colour of Balytsky rocks. R. Ney (Ney, 1968) notes that in Poland Stebnyk beds significantly differ from the typical beds, described by K. Tolvinsky (Tolvinsky, 1927). R. Ney agrees with O. Vyalov (Vyalov, 1966), G. Sizankurt, L. Kudrin, L. Pishvanova and other researchers, who claimed overlap of Stebnyk deposits with the Balych suite. At the same time, M. Ladyzhenskii (Ladyzhenskii, Antypov, 1961) adhered the opinion of B. Buyalsky (Buyalsky, 1930) about the similar age of Stebnyk and Balych deposits. Y. Lazarenko (Lazarenko and others, 1962) states the fact that in some parts of the upper Stebnyk suite the layers of grey and greenish-grey tuffs and dacite tuffites are fixed (vill. Ugersko). It should be noted that these volcanic-sedimentary formations are widespread in places of transition of variegated deposits of the Stebnyk suite into greycoloured salt-bearing deposits. Thus, the age of the sediments, mapped on existing geological maps as the Vorotyshcha suite in considerable areas of Sambir Unit (near the villages of Krasne, Pidlyvche, Lysovychi) is questionable. This conception required the stratification of deposits formed on the stage of sedimentogenesis in the
Miocene within the studied segment of the Central Paratethys.

Postsedimentary aspects of the formation of the rocks of this suite in the northwestern part of the Carpathian Foredeep (Vurva lithofacies complex) are described in various papers (Gurzhiy,1966; Koltun, 1959; Khrushchov, Kompanets,1988).

Researchers from Ukraine and Poland are actively working on a number of practical tasks related to the peculiarities of the geological structure of the Pre-Carpathian region (Bubnjak, 2001; Golonka, 2000; Golonka, Oszczypko, 2000; Oszczypko, 2006; Oszczypko, 2012; Oszczypko, 2014). The questions of stratigraphy of Neogene deposits are also covered by a series of scientific works (Andreyeva-Grigorovich, 1997; Gozhik, 2013; Popov, 2009).

Purpose. Given the complexity of the geological structure of the Carpathian molasse deposits, it became necessary to update the existing data and replenish the scientific base with modern information on the evolution of the BurdigallianLanghian sedimentation basin within the PreCarpathian Foredeep in the context of paleooanography and geodynamics. The obtained research results will help expand the list of search criteria and facilitate the search for solutions to a number of theoretical scientific problems.

Deposits of the Stebnyk suite structurally developed within the Sambir Unit of the Inner part of the Carpathian Foredeep. They are traced as bands and wedges that form the limbs of anticlinal and synclinal folds core, arming some tectonic elements, sometimes inverted to the side of the Carpathians (city Nadvirna). They are cut by differently oriented faults and series of amplitude and no amplitude fractures, that complicate the occurrence of deposits.

Surface outcrops of deposits of the Stebnyk suite within Ukraine are observed as a band extending about $300 \mathrm{~km}$ with a width of about 25 $\mathrm{km}$, which narrows to the southeast. From the Pokuttya fault, the band of Stebnyk deposits' occurrence reaches $2 \mathrm{~km}$, but in some places its presence is not fixed.

Sedimentary sequence of the Stebnyk suite belongs to a single geogeneration complex, whose 
formation was determined by one tectonicsedimentary cycle of sediments accumulation in the epipelagic part of the Central Paratethys. The distinguishing of two lithofacial complexes in the Stebnyk suite (Vurva and Nadvirna) is appropriate, because their formation was caused by tectonic activation of two opposite source areas, which determined their lithological composition (Petruniak, 1977).

Methodology. To obtain our results, we used factual material obtained during field observations, which was analyzed using a complex of lithology-facial, geodynamic and petrographic methods. The authors explored a number of geological routes in the period from 2009 to 2018 and documented in great detail 63 exposures of the Stebnitskaya main outlets (Fig. 1). Based on the data obtained during the passage of azimuthal moves, more than 100 stratigraphic sections were constructed, which, after taking into account all the disjunctive and plicative disturbances, provided reliable information about the true thickness of the sediments under study formed during this tectono-sedimentation cycle. The obtained data were systematized - the authors conducted a series of correlation constructions and derived a generalized lithologic-facies structure of the Burdigallian-Langhian sediments of the Stebnyk suite within the Sambir Unit of the Pre-Carpathian Foredeep in the direction from northwest to southeast (along the line A-A Dobromil-Beregomet) which is shown in Fig. 2. On the basis of the model obtained, it was possible to trace patterns in the conditions of sedimentation and to compile the lithological scheme of the Stebnyk (Burdigal) sediments within the Sambir structural Unit of the PreCarpathian Foredeep in early (1), medium (2) and mid-life (3) periods (Fig. 3).

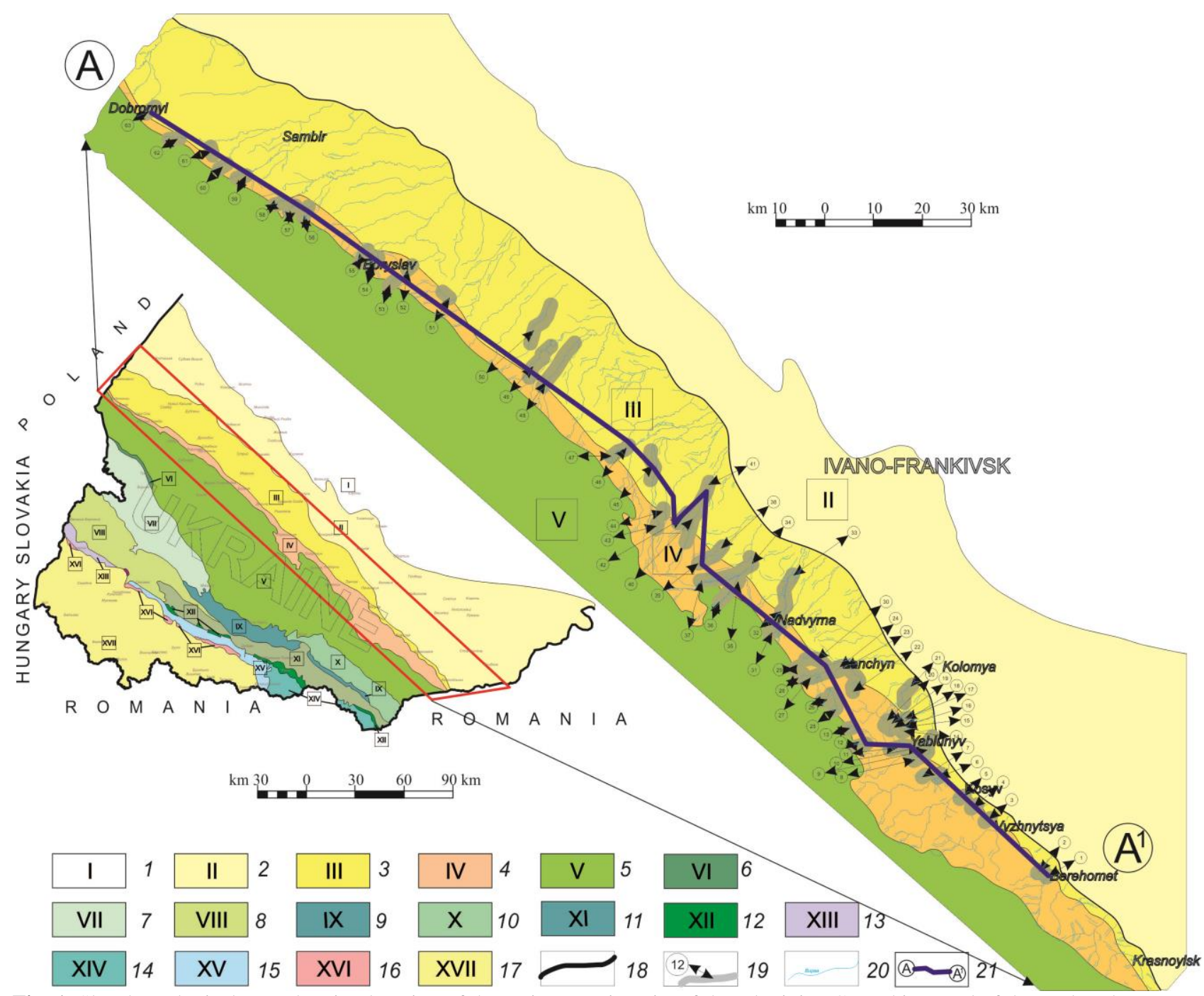

Fig. 1. Sketch geological map showing location of the main tectonic units of the Ukrainian Carpathians and of the analysed outcrops of Burdigallian-Langhian deposits. Geology after Shakin et al. (1976).

1 - East European Platform, 2 - Bilche-Volytsya Unit, 3 - Sambir Unit, 4 - Boryslav-Pokuttya Unit, 5 - Skyba Unit; 6 - Rozluch Unit, 7 - Krosno Unit, 8 - Dukla Unit, 9 - Klimov Unit, 10 - Chornogora Unit, 11 - Porkulets Unit, 12 - Rakhiv Unit, 13 - Magura Unit, 14 - Marmarosh crystalline massif, 15 - Marmarosh Unit; 16 - Pieniny Klippen Belt, 17 - Transcarpathian Depression, 18 tectonic units, 19 - outcrops and their numbers, 20 - rivers, 21 - cross-section line. 


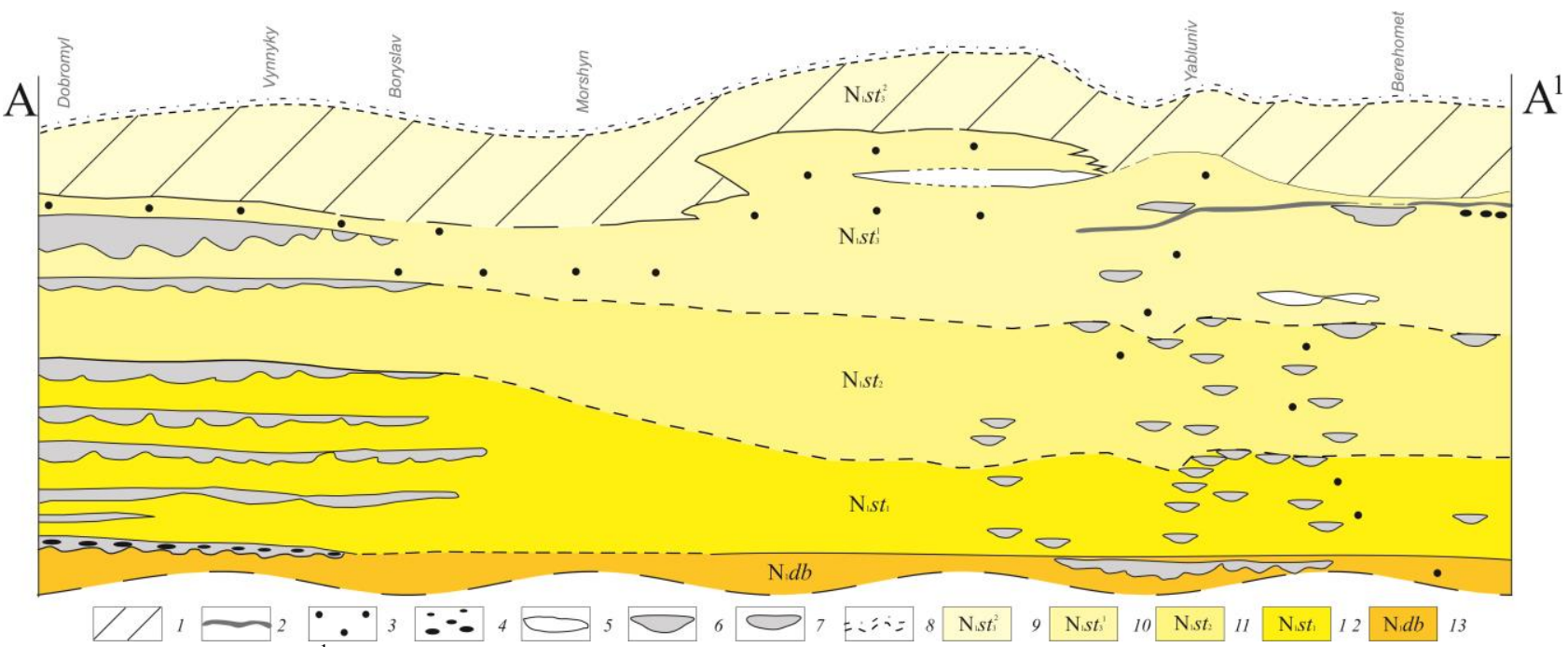

Fig. 2. Cross-section A-A ${ }^{1}$ showing the lithofacies structure of Burdigallian-Langhian Stebnyk suite, Sambir Unit, Carpathian Foredeep (along the line Dobromyl-Berehomet).

Deposits: 1 - grey-coloured psammite-clay with salts; 2 - montmorillonite clays; 3 - grey-coloured clay-psammite; 4 - gravels; 5 multicoloured psammite-clay lenses of mudstones and clays; 6- channel facies' sandstones; 7 - surface facies' sandstones; 8 stratigraphic boundaries with overlapping rocks. 9 - Upper Stebnyk subsuite (salt-bearing horizon); 10 - Upper Stebnyk subsuite (volcanic-sedimentary); 11 - Middle Stebnyk subsuite; 12 - Lower Stebnyk subsuite; 13 - Vorotyshcha (Dobrotiv) suite.

Results. Vurva lithofacial complex (stratotype on r. Tarnava) developed on the northwest of the city Drobobych; Nadvirna (stratotype on the rivers Prut and Luchka) southeastward to the border of Ukraine and Romania.

Lithological set, forming this suite is represented by conglomerates, grvelstones, sandstones, tuff-sandstones, variegated clays, marls, limestones, montmorillonite clays, gypsum, potash and halit salts.

Vurva lithofacial complex (thickness 520$600 \mathrm{~m}$ ) lies on the thin layers of ash-grey silt- clay deposits of the Vorotyscha (Dobrotiv) suite with significant stratigraphic and angular unconformity, which is expressed by hilly or inclined surfaces and erosion incisions.

The main features of the structure of Stebnyk deposits of the Vurva lithofacies complex is defined in most complete sections in vill. Piatnychany (River Tarnava). In particular, an increase in thickness of sandstone layers up the geological section with reduction of gravel grains is observed there.

Underlying rocks are overlapped by the layer of complicated structure, which is characterized as follows near the village Tarnawa (bottom to top): greenish-grey conglomerate $(0.3 \mathrm{~m})$, aggregated of pebbles of exotic composition (size 2-5 cm) with numerous cavities of leaching, lined with crystals of dolomite and quartz. This pack is covered by the layer of dark-grey coarse-grained sandstone (0.3$0.4 \mathrm{~m}$ ) with inclusions of fragments of grey and pink clay and changing by sandstone $(4 \mathrm{~m})$ with fractional carbonaceous detritus, that can be traced along the oblique stratification. Overlying clays are interbedded with siltstones and sandstones $(4 \mathrm{~m})$ and a layer of light grey polymictic sandstone $(1 \mathrm{~m})$ is characterized by layered obliquely laminated rythmoliths, whose thickness reduces up the geological section . The total thickness of the layers described above is $12 \mathrm{~m}$.

Granular size of the rocks changes dramatically along the strike line: small-pebble conglomerates and gritstones (near vill. Tarnava) and coarse-grained pebble deposits (vill. Stara Ropa).

The results of field and complex lithofacial investigations of Miocene deporits, allowed the author to divide this complex into three subsuits lower, middle and upper.

Lower subsuit (thickness 293-300 m) is composed of conglomerates, gritstones, sandstones, clays, less limestones. It is made up of a number of regressive rock packs, thickness from 20 to 70 meters. Character of their interbedding reflects their cyclic formation, which occurred during sedimentation. In the middle of these packs the layers with abnormally increased thickness (0.2-0.5 m) are observed. By the way, thick strata of sandstones at the base, are usually enriched with gritstone component of oblique lamination river type.

Middle subsuite (thickness 100-105 m) is characterized by a predominance in the structure of a cherry-red clays, less brownish-black and greenish-grey with a subordinate number of layers of sandstones and gritstones (0.05 - $0.2 \mathrm{~m})$. Spatially the deposits of this subsuite are sustained by strike line. 


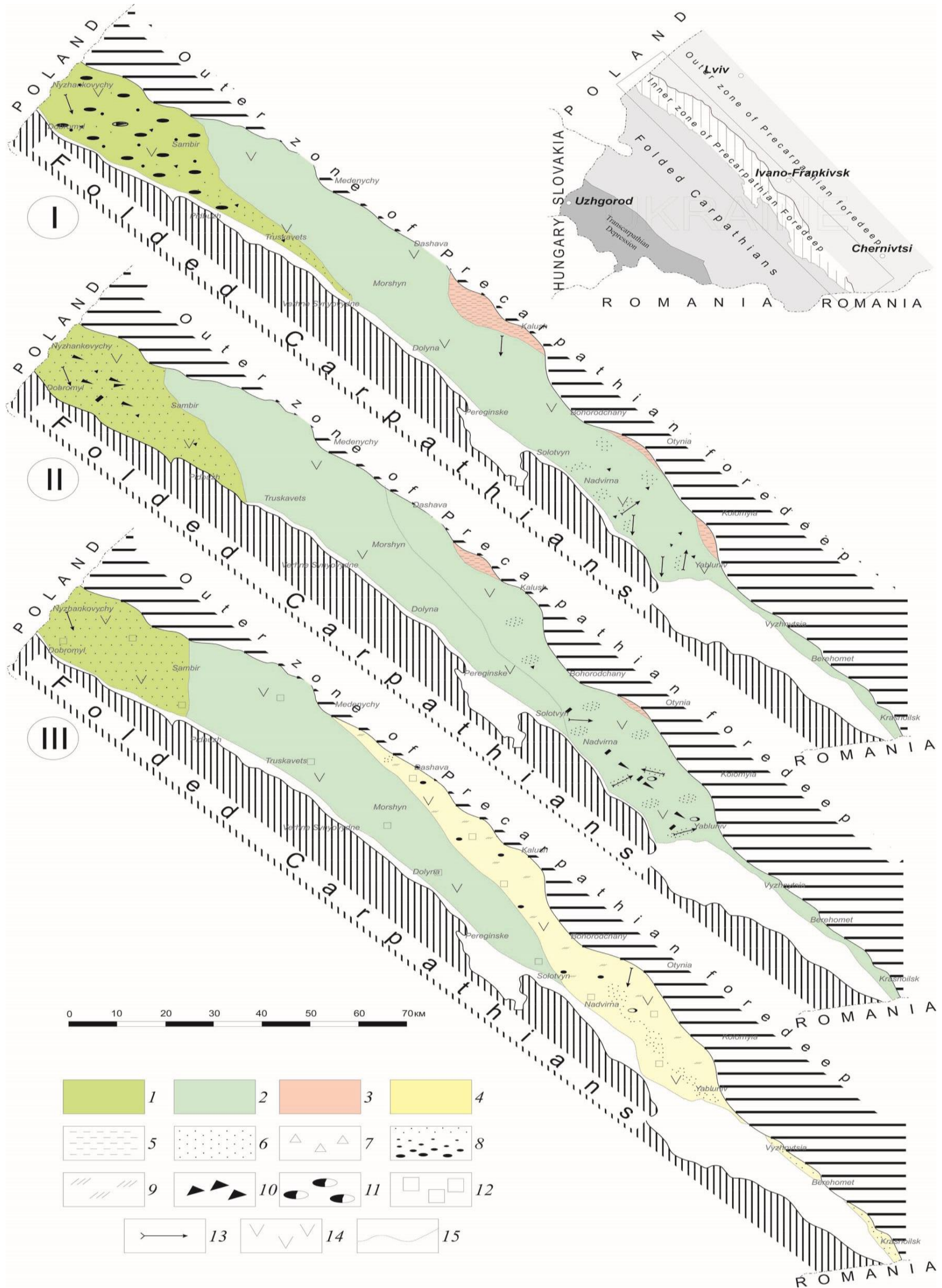

Fig. 3. Lithofacial shemes of Burdigallian-Langhian deposits of the Sambir Unit, Carpathian Foredeep, in Early-(1), Middle-(2) and Late Stebnyk (3) periods.

Deposits: 1 - gravel-psammite; 2 - psammite-clay; 3 - clay-psammite; 4 - clays; 5 - clays and mudstones; 6 - with a high content of psammitic component; 7 - breccia; 8 - gravels; 9 - montmorillonite clays; 10 - pebbles of Menilite shales; 11 - conglomerates and pebbles of exotic material; 12 - salt-bearing strata; 13 - the direction of transport of terrigenous material in the sedimentary basin; 14 - variegated; 15 - lithofacies' boundaries. 
Upper subsuite (thickness 124-135 m), similar to the lower one, is composed by rock packs, but its deposits are characterized by a high content psammite component. Sandstone layers are enriched with gritstones component only at the base and contain significant amounts of carbonaceous plant detritus. Its clusters highlights the stratification and shows the dislocation mechanism of the sediments. Thin rhytmic packs of rocks, which fill the space between the layers of sandstone, are similar in structure to their counterparts in the lower subsuit, but contain more greenish-grey layers. In the middle of the packs of deposits, parallel to layering, the hollow carbonate concretions with shrinkage textures are fixed, which correspond to the ones previously described by V. Koltun (Koltun, 1959). Up the geological section the thickness and the number of layers of sandstone increases, and vice versa, dramatically reduces the thickness of thin layers that divide them. In some sandstone packs the textures of diagenetic sediments dislocation are observed. These deposits are covered by grey-coloured psammitic-clayey layer with signs of salinization. In the basin of the River Bystrytsya Pidbuzhska (vill. Vynnyky) typical footprints of birds have been found. Various prints are also described in Dobrotiv and Stebnyk suite by O. Vyalov (Vyalov, 1965).

Nadvirna lithofacial complex (thickness 570$660 \mathrm{~m}$ ) is represented by psammite-clay layers with complicated structure and with inherited character of sedimentation from Dobrotiv suite. This complex rests conformably on sediments of Dobrotiv suite, the stratigraphic boundary of which is traced by the appearance of red clay layers. On the background of thin-layer, mostly clayey variegated strata the layers and lenses of sandstone (1-10 m) occur. On their surface throughout the entire thickness of the geological section the numerous prints of physical events and vertebrates are fixed. Gravel "exotic material", whose content in the rocks increases up the geological section, is traced only in sediments of the upper undersalt subsuite.

Lower subsuite (thickness 120-150 m) is composed by the similarly built packs of lithological units $(3-20 \mathrm{~m})$, repeated 6-15 times in its structure. These packs are composed of siltstones, sandstones, clays and marls. The lower parts of packs contain clays with domination of greenish-grey colour over pink-red. Up the geological section the content of psammite component and carbonate increases; some layers of marl also appear. At the top of the packs the replacement of their top parts by underwater surface fluvial facies is often fixed, which is normal for such geogenerations. At the level of 40-50 m from the base of the subsuite in some geological sections on the base of the siltstone layers are fixed star-shaped clusters of the strontiobarite $\mathrm{SrBa}\left(\mathrm{SO}_{4}\right)_{2}$ and "counterprints" of net-shaped shrinkage cracks. There is the regularity of uneven development of clay layers even in closely spaced outcrops. This phenomenon, without clear evidence of tagging, seems to reflect the facies variability and specificity of formation of deposits. This trend is observed in the regional plan of Sambir Unit as an example of geological sections (in the ratio of clay to other rocks): vill. Yabluniv - 58\%; vill. Delyatyn - 65\%; vill.Lanchyn - 70-56\%; vill. Rozsilna - 84\%; vill. Zhuraky $-56 \%$.

In the rocks of the Lower Stebnyk subsuite numerous finds of physical facts (shrinkage cracks, prints of raindrops, cavity of halite and ice crystals, ripples), traces of vertebrates (storks, sandpipers, unknown birds, gulls, gazelles, horses, lynxes, foxes, pigs, frogs et al.) and carbonized remains of plants and trees, algae prints are traced.

The middle subsuite (thickness 190-240 m) is very different from the lower one by the ratio of the lithological set, alternating in different combinations in complicated composed packs of rocks with thickness of 20-45 meters. Four types of such packs are allocated there: 1) prevalence of greenish-grey clay layers and siltstones over the red ones; 2) reddish clay layers over the greenish-grey ones; 3 ) marl layers, alternating with other rocks in the total mass of pink-red colour; 4) sandstones and siltstone layers $(0.25 \mathrm{~m})$ among layered clays with layers of sandstones with thickness of more than 1 $\mathrm{m}$.

The tendency of changing of geochemical environments from less- to more oxidizing in the basin of sedimentation fully reflects the combination of the first three packs of sediments.

Preferably up the geological section the redcoloured layers are succeeded by psammite-marl sediments. Distribution of the thick sandstone strata of this subsuite is irregular and usually they occur in erosion incisions with rubble and gravel of consedimentary erosions. In the middle part of the Nadvirna lithofacial complex in the layers of sandstones the presence of "exotic" gravel material is fixed (vill. Yabluniv).

The upper subsuite (thickness 200-250 m) of the Nadvirna lithofacial complex is expressed by two successions. The lower (volcanicsedimentary) succession is composed of ash-gray and brown tuffs and tuffites, which were postsedimentally changed and represent lithological complex of complex mineralogical composition (Petruniak, Cheremisska, 2013; Petruniak, Iaremchuk, 2012). Epigenetic veins of gypsum with subparalel to the bedding planes are 
observed in layers. Up the geological section the trend to increase in "exotic" gravel material content is fixed. Thick sandstone layers are lensshaped and developed unevenly. The upper border of this succession should be traced on the top of thick gritstones and sandstones, sometimes enriched by the carbonized remains of plants (vill. Utoropy) or disappearance of red coloured rocks. The dominating contrasting change of the sediments' colour is associated with contrasting fluctuations of redox conditions in the sedimentary basin, which has been described by a number of researchers of sedimentary basins. So, A. Perelman (Perelman, 1972) on example of dry steppes and deserts of Central Asia and Kazakhstan found that in areas of salt marshes is created the contrasting oxidative environment with free oxygen to $\mathrm{Eh}+500 \mathrm{mV}$, which vertically changes for reducing with the value of Eh $500 \mathrm{mV}$. In our opinion, such a phenomenon has occurred in the Miocene salt layers of the studied region of the Carpathian segment of the Paratethys (as a preserved geochemical environment in areas of salt brine discharge in surface conditions), where there is a transfer of ferrous iron salt deposits into the oxidized form of its hydroxides.

The upper succession (salt-bearing horizon). Sediments are characterized by polifacial composition and are represented by certain types of geological sections. As outlined above, the saltbearing horizon is stratigraphically conformably underlain by red-pink succession of clay layers, sandstones and gypsum. In this horizon a number of facial differences that appear in the literature under the names of Utorop, Lanchyn, Trostianets, Kalush, Balych layers are known.

Originality. Vurva and Nadvirna lithofacial complexes are a single genetical geogenerational formation, which in both cases by the character of sedimentation is regressive. In some cases, rhythmograms of deposits begin from the bituminous black clays (0.05-0.46 m).

The first complex lies on the eroded surface of the Vorotyscha (Dobrotiv) suite. Among the gravel-pebble material of the underlying succession, the fragments of amygdaloidal diabase are fixed. The Nadvirna complex retains inherited from Dobrotiv suite the character of sedimentation. The gravel component, represented in it, is in the upper part of the red coloured section and contains fragments of albitized diabase of the trachytoid structure.

Development of a clay horizon of montmorillonite in the Nadvirna facial complex has a regional character. In thin sections of rocks from typical Stebnyk and Balych suites the pyroclastic rocks structure, indicating the manifestations of volcanic activity, is clearly seen. Its centres were probably located on the southwestern slopes of the Carpathian segment of Paratethys.

In the Vurva lithofacial complex, unlike the Nadvirna one, the montmorillonite clay horizon was not found. Despite the fact that the successions of both complexes are similar in terms of thickness and formation and reflect some tectonic-sedimentation regime of sedimentation, we believe that they are diachronic.

In the area of tectonic joints of the Sambir and Bilche-Volytsya Units, along the valleys of waterways the gradual transition of the complexes described above from multicoloured to greycoloured with montmorillonite clays and rocks with signs of solenization is traced. The correlation constructions allow us to assume that the grey-coloured Balych suite in the facial relation is analogous to Stebnyk suite (Buyalsky, 1930).

The occurrence and development of montmorillonite and zeolites is the specific issue under this topic. Zeolites in the Vurva complex are represented by only a few grains of analcime, but in Nadvirna - by phillipsite, stilbite, mordenite, natrolite.

In the structure of the monolithic Stebnyk suite of Sambir Unit on the watershed of the rivers Cheremosh and Limnytsya, there is a frequent repetition in geological section of the salt horizon and layers of montmorillonite clays. This fact illustrates the complexity of the tectonic structure of the Sambir Unit and features of tectonogenesis of the Carpathian segment of Paratethys.

On the base of stratigraphic correlation and a number of selected stratigraphic levels of copper mineralization (Petruniak, 1977), layerings of the Stebnyk suite can be divided into three undersuits: the lower, middle and upper (with volcanicsedimentary sequence and salt horizon). The lithofacial structure of layers of the suite is shown in Fig. 2. The lithological scheme of the lower, middle and upper subsuites of BurdigallianLanghian age is shown in Fig. 3.

For the carrying out of paleooceanographic reconstructions it is important to establish the parameters of th Burdigallian-Langhian sedimentary basin. Data of deep drilling in the area on the oil field Lopushnia (Glushko, Kulchytsky, 1995) suggests that the western coastline of the Carpathian sedimentary basin of this age should occur at the border of Krosno (Silesian) and Chornogora Units. Probably, this border is traced under the pulled over crystalline ledge of the Chyvchyn mountains. 

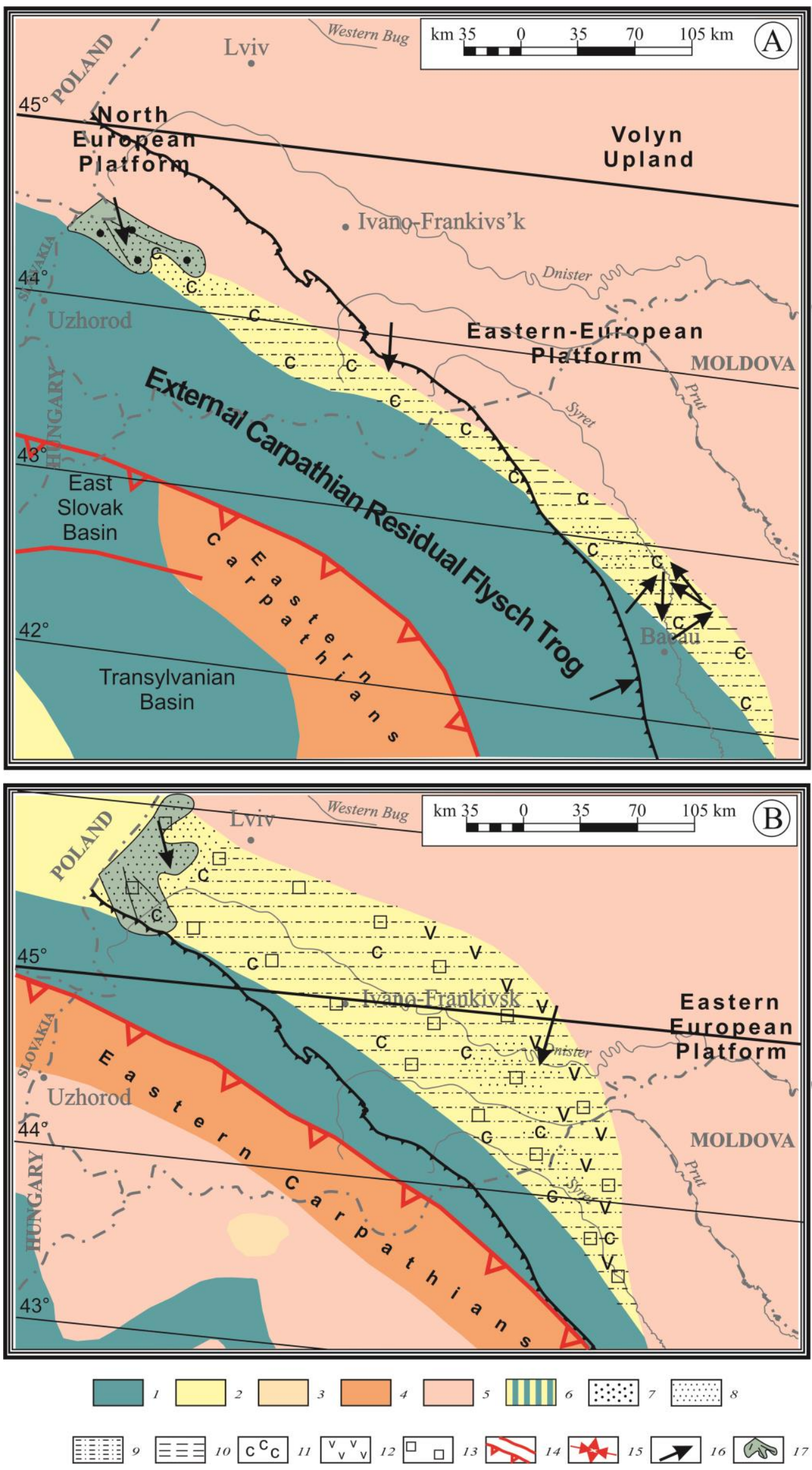

Fig. 4. Sedimentologo-paleoceanographic model of formation of the Burdigallian-Langhian sediments of the Stebnyk Formation, Sambor Unit, Pre-Carpathian Foredeep (after Dekurt, 2000). A-Early and Middle Stebnyk time; B-Late Stebnyk period. Deposits: 1 - deep sea (trog), 2 - coastal-marine (terrigenous), 3 - lacustrine-alluvial, 4 - mountainous terrain, 5 - platform; Precipitation: 6 - gravel-psammate, 7 - psammate, 8 - psammate-clay, 9 - clay, 10 - red-coloured, 11 - volcanogenic, 12 - saline, 13 - fault and thrusts; 14 - direction of demolition of the terigene material; 15 - Paleo-Wisla. 
On the palaeographic schemes (Derkut ta., 2000), the pre-Carpathian sedimentary basin in the Burdigallian-Langhian age is located between 42 and 46 parallels of latitude, which is the Unit of the tropical and subtropical climatic belt of the variablyhumid climat (Ushakov ta., 1984). For the entire period of the formation of the Stebnyk basin it was shifted in relation to the equator, which in turn, together with the other geological factors, had an essential influence on sedimentary environments. The sedimentation of the lower part of the middle sub-suite (Fig. 4A) took place in the basin, located between the 42nd and 45th parallels of latitude. Taking into account the paleosurface and the thick channel facies of sandstones, the River Paleo-Wisla could be considered as the main source of delivery of the clastic material. The near-surface channel sandstone facies in the southeast are of less extent, so they should be referred to the deposits of shallow water arteries and temporary water streams that had different directions of motion, which can be explained by the peculiarities of the paleosurface in this area. The main lithological complex of this time is represented by the variegated psammite-clayey sediments with the corresponding amount of the psammitic component, which is widespread in the areas with paleo-channels. On the south-eastern boundary of the Pre-Carpathian sedimentary basin clay sediments occur. In the Langhian period (Fig. 4B) sedimentation occurred between the 43rd and 46th parallels, but a number of features indicate that the terrigenous province was formed under an arid and volcanogenic-sedimentary type of lithogenesis. The sediments that are at the top of the stratigraphic section indicate the completion of the process of formation of the Stebnyk tectonic-sedimentary cycle, reflecting the complexity of the geological processes occurring during the final closure of the Paratethys in the Carpathian region. The formation of Upper Stebnyk deposits took place in two main stages: first, a volcanogenic-sedimentary group with montmorillonite layers was formed within the total mass of hydromica-bearing pelites and salt formation, which is characteristic of the final stage of mineral formation under arid lithogenesis.

The results of the study show that the Stenbyk Formation of the Carpathian Foredeep represents an integral geo-generative complex that has been formed in a certain tectonic sedimentation cycle, has a completed character of mineral formation and is unique within the Carpathian Paratethys segment.

Practical significance. A detailed study of the lithological composition of the Miocene deposits of the Pre-Carpathian Foredeep, the reconstruction of the geodynamic conditions of the sedimentation basin and the history of the geological development of the region allows us to solve a number of scientific and practical questions. The subdivision of the strata of rocks, the formation of which occurred in several stages of a single tectonic-sedimentation cycle, will help to update the existing information regarding the age of the Stebnyk suite. The presence of a detailed model for the formation of Burdigallian-Langhian deposits allows us to identify a number of criteria for the search for minerals.

Conclusions. According to the model of paleooceanographic situation in the CarpathianBlack Sea segment of the Tethis Ocean in the Middle Cretaceous the authors pointed out a number of islands. It is possible that in the BurdigallianLanghian age they were firm terrigenous formations and served as provinces of supply: for the Vurva lithofacies complex - Sventokshynsky island, and for Nadvirna - Byrlad and Dobrogean Islands. In general, the Burdigallian-Langhian deposits were formed under conditions of lacustrine-alluvial plains of arid climate, symbolizing the final closure of the Central Paratethys.

\section{References}

Andreyeva-Grigorovich A., Kulchytsky Ya, Gruzman A., Lozynyak P., Petrashkevich M., Portnyagina L., Ivanina A., Smirnov S., Trofimovich N., Savitskaya N., Shvareva N., 1997. Regional stratigraphic scheme of Neogene formations of the Central Paratethys in the Ukraine. Geologica Carpathica, Vol. 48(2), 123 - 136 (in English).

Bubniak I., Bubniak A., Kilyn I., Popp I., 2001. Strukturno-sedymentolohichni doslidzhennia dobrotivskykh vidkladiv Peredkarpatskoho prohynu (raion Nadvirnoi)[ Structural and sedimentological studies of the Dobtorian deposits of the Pre-Carpathian foredeep (Nadvyna region)]. Pratsi Nauk. tov-va im. Shevchenka. Heol. zb., 5, 84-93 (in Ukrainian).

Burov V. S., 1971. Negenovye otlozhenija Predkarpat'ja [Neogene deposits of the Precarpathian region]. Geologicheskoe stroenie i gorjuchie iskopaemye Ukrainskih Karpat. Naukova dumka, Kyiv (in Russian).

Vjalov O. S., 1966. Sledy zhiznedejatel'nosti organizmov $\mathrm{i}$ ih paleontologicheskoe znachenie [Traces activity of organisms and their paleontological value]. Naukova dumka, Kyiv (in Russian).

Vyalov O., 1965. The stratigraphy of the Miocene molasses of the Precarpathian area[The stratigraphy of the Miocene molasses of the Precarpathian area]. Naukova dumka, Kyiv (in Russian).

Hlushko V. V., 1995. Problemni pytannia Karpatskoho rehionu [Problematic issues of the Carpathian region]. Vydavnychyi tsentr Lviv. un-tu, Lviv (in Ukrainian).

Hozhyk P., Semenenko V., Andreieva-Hryhorovych A., Maslun N., 2013. Koreliatsiia rehioiarusiv neohenu Tsentralnoho i Skhidnoho Paratetysu (Ukrainy, 
Rosii, Azerbaidzhanu, Hruzii) [Correlation of the Neogene regeneration of Central and Eastern Paratethys (Ukraine, Russia, Azerbaijan, Georgia)]. Heoloh Ukrainy, 2, 36-60 (in Ukrainian).

Gurzhij D. V., 1966. Litologija molass Predkarpat'ja [Lithology of Precarpathian molasses]. Naukova dumka, Kyiv (in Russian).

Koltun V. I., 1959. Litolohiia stebnytskykh vidkladiv pivnichno-zakhidnoi chastyny Radianskoho Peredkarpattia [Lithology of the Stebnyk's deposits of the northwestern part of the Soviet Precarpathians]. Vydav. AN URSR, Kyiv (in Ukrainian).

Kul'chickij Ja. O., 1961. Osnovnye cherty tektoniki [Main features of tectonics]. Geologija i poleznye iskopaemye Ukrainskih Karpat. Ch. II. Izd. L'vov. un-ta, Lviv. (in Russian).

Ladyzhenskij N.R., 1961. Geologicheskoe stroenie i gazonosnost' Sovetskogo Predkarpat'ja [Geological structure and gas content of the Soviet Precarpathians]. Gostoptehizdat, Moscwa (in Russian).

Lazarenko Ye. K., 1962. Mineralohiia osadochnykh utvoren Prykarpattia [Mineralogy of sediments of the Precarpathians]. Vydavnychyi tsentr Lviv. untu, Lviv (in Ukrainian).

Petrunjak M. D., 1977. Prostranstvennaja lokalizacija medictyh peschanikov $\mathrm{v}$ Prikarpat'e [Space localization of the copper sandstones in the Precarpathians]. Mineralogija osadochnyh obrazovanij, Vyp. 4 (in Russian).

Petruniak M. D., 2013. Autyhenni mineraly osadovoho tsyklu v Peredkarpatti, yikh zonalnyi rozpodil ta stadiinist yikh formuvannia [Authigenic minerals of the sedimentary cycle in the Precarpathian, their zonal distribution and stages of their formation]. «Suchasni problemy heolohii». Kyiv (in Ukrainian).

Petruniak O. M., 2012. Osoblyvosti mineralnoho skladu miotsenovykh hlyn stebnytskoi svity Ukrainskykh Karpat [Mineralogical composition of the Miocenic clays from the Stebnik's suite of the Ukrainian Carpathians]. Min. Zb, 62(1) (in Ukrainian).

Perel'man A. I., 1972. Geohimija jelementov v zone gipergeneza. Geochemistry of the elements in the zone of hypergenesis .Nedra, Moscwa (in Russian).

Popov S., Ahmet'ev M., Lopatin A. i dr., 2009. Paleogeografija i biogeografija bassejnov Paratetisa. Chast' 1. Pozdnij jeocen-rannij miocen [Paleogeography and biogeography of the Parathethys basins. Part 1. Late Eocene-early Miocene]. Nauchnyj mir, Moscwa (in Russian).

Senkovskyi Yu., Hryhorchuk K., Hnidets V., Koltun Yu., 2004. Heolohichna paleookeanohrafiia okeanu Tetis [Geological paleooceanography of the Thetis Ocean]. Naukova dumka, Kyiv (in Ukrainian).

Shakin, V., Burov, V., Vialov, O., Glushko, V., Kruglov, S., Petrashkevich, M., Temnjuk, M., 1976. Geologicheskaja karta Ukrainskih Karpat i prilegajushhih progibov [Geological map of the
Ukrainian Carpathians and adjoining areas 1:200 000]. KyivGeologia, Kyiv (in Russian).

Ushakov S. A., Jasamanov N. A., 1984. Drejf materikov i klimaty Zemli [Continental drift and Earth climates]. Mysl', Moscwa (in Russian).

Hrushhev D. P., Kompanec G.S., 1988. Litologija galogennyh i krasnocvetnyh formacij Predkarpat'ja[Lithology of halogenic and red coloured formations of the Precarpathians]. Naukova dumka, Kyiv (in Russian).

Bujalski B., 1930. Budova geologiczna przedgórza Karpat Wchodnich między Łukwią a Rybnicą [The geological structure of the foothills of the Eastern Carpathians between the rivers Lukva and Rybnica. Spr. P.I.G, Warszawa, VI(2) (in Polish).

Dercourt J., Gaetani M., Vrielynck B., Barrier E., BijuDuval B., Brunet M.F., Cadet J.P., Crasquin S., Sandulescu M. (eds)., 2000. Atlas Peri-Tethys paleogeographical maps. CCGM/CGMW, Paris.

Golonka J., 2000. Cambrian-neogen : plate tectonic maps .Wyd 1. Kraków b Wydawn. Uniwersytetu Jagiellonskiego.

Golonka J., Oszczypko N., Slączka A., 2000. Late Carboniferous-Neogene geodynamic evolution and paleogeography of the circum - Carpathian region and adjacent areas. Annales Societatis Geologorum Poloniae, T. 70, 107-136.

Ney R., 1968. The role of the Krakow's rigle in geology of the Carpathian Foredeep and distribution of brine and gas [The role of the Krakow's rigle in geology of the Carpathian Foredeep and distribution of brine and gas]. Geology publishing, Warsaw (in Polish).

Oszczypko N., 2006. Powstanie i rozwój polskiej części zapadliska przedkarpackiego[Establishment and development of the Polish part of the PreCarpathian foredeep]. Przegląd Geologiczny, 54(5), 396-403 (in Polish).

Oszczypko N., Uchman A., Bubniak I., 2012. Foreland provenance of thick conglomerates in the early stage of the Carpathian Foredeep development: the case of the Sloboda Conglomerate (Lower Miocene), western Ukraine. Geological Quarterly, 56(4), 393-408.

Oszczypko N., Uchman A., Bubniak I., 2014. The Dobrotiv Formation (Miocene) in the BoryslavPokuttya and Sambir nappes of the Ukrainian Carpathians: a record of sedimentary environmental change in the development of the Carpathian Foredeep Basin. Geological Quarterly, 58( 3), 393-408.

Tołwinśki K., 1927. Z geologji południowej strefy przedgórza polskich Karpat Wchodnich [From the geology of the foothills of the southern zone of the Eastern Polish Carpathians]. Spr. P.I.G., Warszawa, IV(1-2) (in Polish).

Van Houten F.B., 1964. Origin of red beds-unsolved problems. Problems of Paleoclimatology. Interscience Publishers, London (in English).

Zuber R., 1883. Studia geologiczne we Wschodnich Karpatach [Geological studies in the Eastern Carpathians. Cz.II. Kosmos, Lwów (in Polish). 